\title{
Internal structure and permafrost distribution in two alpine periglacial talus slopes, Valais, Swiss Alps
}

\author{
Cristian Scapozza ${ }^{\mathrm{a}, *}$, Christophe Lambiel $^{\mathrm{a}}$, Ludovic Baron ${ }^{\mathrm{b}}$, Laurent Marescot ${ }^{\mathrm{c}}$, Emmanuel Reynard ${ }^{\mathrm{a}}$ \\ a Institute of Geography, University of Lausanne, Anthropole, 1015 Lausanne, Switzerland \\ b Institute of Geophysics, University of Lausanne, Amphipôle, 1015 Lausanne, Switzerland \\ c Geography Unit, Department of Geosciences, University of Fribourg, Chemin du Musée 4, 1700 Fribourg, Switzerland
}

\section{A R T I C L E I N F O}

\section{Article history:}

Received 31 August 2010

Received in revised form 13 April 2011

Accepted 13 May 2011

Available online 19 May 2011

\section{Keywords:}

Permafrost

Talus slope

Borehole drilling

Electrical resistivity tomography (ERT)

Swiss Alps

\begin{abstract}
A B S T R A C T
In order to determine the spatial extension and the characteristics of permafrost within alpine talus slopes, two sites located in the western part of the Swiss Alps were studied using borehole drilling and electrical resistivity tomography (ERT) profiles. Three boreholes were drilled along an upslope-downslope transect in both talus slopes. In both sites, frozen sediments are present only in the two lowest boreholes, whereas the upper borehole does not present ice. This stratigraphy is confirmed by ground temperatures registered in the boreholes. In each site, three upslope-downslope ERT profiles were crossed with five, respectively four horizontal ERT profiles. All the upslope-downslope profiles show a difference in resistivities between the upper and lower parts of the slope, where a large resistive body with values higher than $35 \mathrm{k} \Omega \mathrm{m}$ is present. In the uppermost part of the profiles, the resistivities are lower than $10-15 \mathrm{k} \Omega \mathrm{m}$. The borehole data allowed the stratigraphy obtained from the ERT inverted profiles to be validated, with regards to the distribution of frozen sediments as well as the depth of the detected structures. The results confirm that, in the two studied sites, permafrost is present in the lower sections of the talus slopes, whereas it is absent in the upper parts. Finally, the analysis of the talus structure showed that the permafrost stratigraphy, and in particular the ice content, may be an important element of interpretation of the palaeoclimatic significance of an alpine talus slope.
\end{abstract}

(c) 2011 Elsevier B.V. All rights reserved.

\section{Introduction}

Within the framework of scientific research related to the geomorphological and climatic evolution of the Alps during Lateglacial and Holocene, little interest has been accorded to the study of alpine periglacial sedimentary terrains (in particular, rock glaciers and talus slopes), in contrast to the climatic and environmental changes documented from botanical and zoological proxies (e.g. Burga and Perret, 1998), glacier-length variations (e.g. Jörin et al., 2006) and solifluction and landslide activity changes (e.g. Frenzel, 1993; Borgatti and Soldati, 2010). In recent decades, the most important part of alpine periglacial field studies focused on the structure, dynamics and age of rock glaciers (e.g. Barsch, 1996; Haeberli et al., 2006). However, talus slopes are one of the most common landforms in many mountain environments. Several geomorphological and sedimentological studies have focused on their morphology, structure and origin (e.g. Francou, 1988; van Steijn et al., 2002; Sass, 2006), but little research has focused on the permafrost distribution and stratigraphy within talus slopes (e.g.

\footnotetext{
* Corresponding author. Tel.: +41 2169230 77, +4 417953594 22; fax: +4121692 3075 .

E-mail address: cristian.scapozza@unil.ch (C. Scapozza).
}

Lütschg et al., 2004; Lambiel and Pieracci, 2008; Phillips et al., 2009) or on the palaeoclimatic significance of their ice content (e.g. Francou, 1977; Berthling et al., 2000).

Various techniques have been applied to investigate the permafrost distribution and structure in alpine talus slopes, focusing on thermal measurements and 1D and 2D geophysical prospecting (e.g. Haeberli, 1975; Otto and Sass, 2006; Lambiel and Pieracci, 2008; Scapozza et al., 2011). However, due to the restricted drilling possibilities, only a few studies have focused on the verification of geophysical models of the permafrost distribution by direct in situ measurements and observations at depth (e.g. Phillips, 2000; Delaloye, 2004; Lütschg et al., 2004).

One of the earliest pioneer studies on permafrost distribution in alpine talus slopes was carried out by Haeberli (1975) at the Flüela Pass (2380 masl), in the Eastern Swiss Alps.

Prospecting with refraction seismic soundings showed that frozen sediments were present in the lower part of the slope and absent in the upper part. Recent studies carried out in other regions of the Swiss Alps focused on the controlling factors and confirmed the heterogeneity of permafrost distribution in talus slopes (e.g. Lerjen et al., 2003; Lütschg et al., 2004; Delaloye and Lambiel, 2005; Lambiel, 2006; Lambiel and Pieracci, 2008; Pieracci et al., 2008; Phillips et al., 2009; Scapozza et al., 2011). Due to the lack of in situ evidence, there is, nevertheless, a paucity of studies focusing on the stratigraphy of 
periglacial talus slopes (e.g. Berthling et al., 2000; Otto and Sass, 2006; Sass, 2006, Scapozza et al., 2010a).

The aim of the present study was to examine the local permafrost distribution in two alpine talus slopes of the western Swiss Alps and to study its stratigraphy and extension. In order to fulfil this objective, direct information was collected by analysing borehole stratigraphy and by recording temperature measurements and pictures in boreholes. The understanding of the lateral extension of the prospected structures was made possible by recording electrical resistivity tomography (ERT) data.

\section{Study area and site characteristics}

The two talus slopes studied are located in the western part of the Swiss Alps (Canton of Valais, in the Verbier and Arolla areas), on the southern side of the Rhone valley (Fig. 1A). The region is included in the Penninic and Austroalpine tectonic domains. The southern side of the Rhone river valley is characterised by a relatively dry climate. At 2500 masl, the calculated mean annual precipitation is approximately $1500 \mathrm{~mm}$, whereas the extrapolated mean annual air temperature (MAAT) is about $-1{ }^{\circ} \mathrm{C}$ (Reynard, 1999). According to Lambiel and Reynard (2001), the potential minimal altitude of discontinuous permafrost in the region ranges between about 2400 masl for northern orientations and about 2700 masl for southern orientations. Two periglacial talus slopes were investigated: (1) a large slope with complex morphology (Les Attelas talus slope, Verbier area, $46^{\circ} 06 \mathrm{~N}$, $7^{\circ} 17$ E, Figs. $1 \mathrm{~B}$ and $2 \mathrm{~A}$ ) and (2) a talus cone-protalus rampart sequence situated above a relict rock glacier (Petit Mont Rouge talus slope, Arolla area, $46^{\circ} 01$ N, $7^{\circ} 27$ E, Figs. $1 \mathrm{C}$ and 2B).
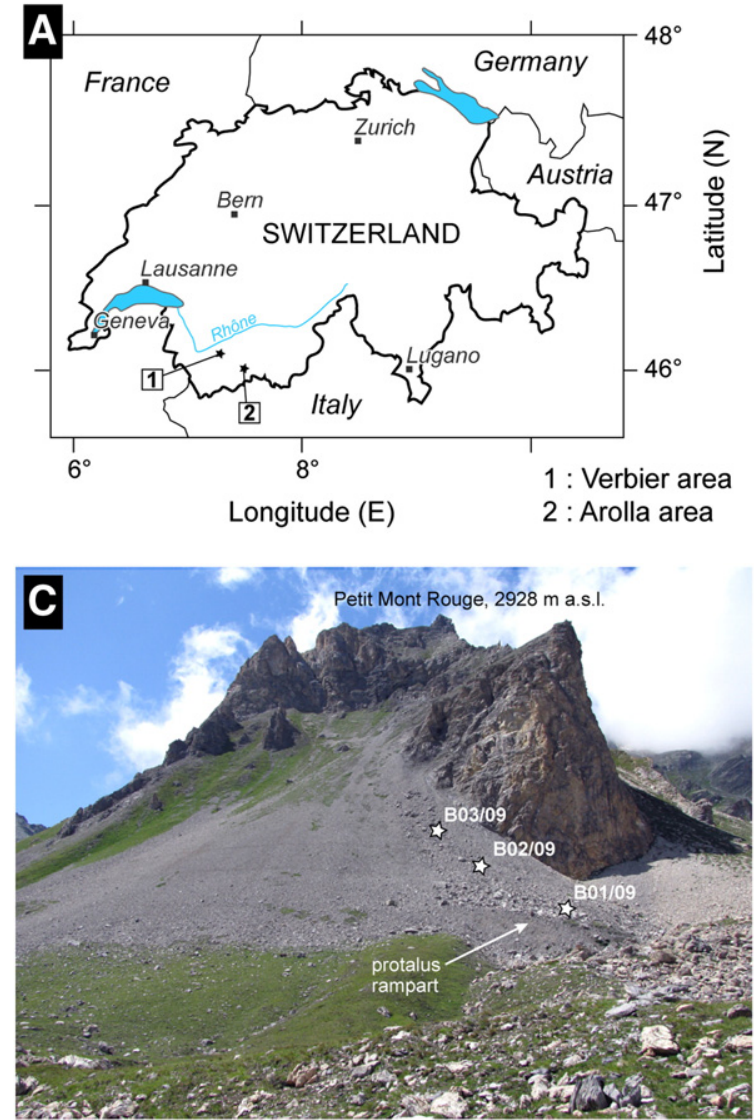

In this paper, according to the descriptions and considerations proposed by Barsch $(1969,1996)$, Haeberli (1985) and Lambiel and Pieracci (2008), the term "protalus rampart" is used to define small permafrost creep phenomena (embryonal active talus rock glaciers) in contrast to the definition of protalus rampart as a nivation ridge proposed by Ballantyne and Benn (1994) and Shakesby (1997).

\subsection{Les Attelas talus slope}

The Les Attelas talus slope is a cone-shaped landform composed of micaschists with amphibolites and paragneiss (in particular sericitechlorite schists). The average inclination of the talus is $29^{\circ}$. It is located between 2620 and 2800 masl on the west-facing flank of the Mont Gelé (3023 masl) (Fig. 1B). On the upper section of the slope, dominated by a $200 \mathrm{~m}$ high rock wall, the fine to medium sized debris cover, composed of small boulders $(<30 \mathrm{~cm})$ and cobbles in a pebble matrix, is affected by solifluction processes. The resulting lobes are partially covered by vegetation (alpine meadow). The middle section, situated at the base of the solifluction lobes, contains medium sized boulders ( 30 to $50 \mathrm{~cm}$ ) and cobbles, in a matrix of fine-grained debris, which are often covered with very scarce vegetation. The lower section, completely lacking in vascular plants, is made up exclusively of decimetre- to metre-sized boulders. The size of the clasts increases downslope, where gravel and sand are absent on the surface.

Small creeping lobes suggest the presence of frozen sediments supersaturated in ice at the base of the slope. In the southern part of the slope, these lobes are coalescent with a small rock glacier, probably inactive (Lambiel, 2006). The limited motion of the entire slope has been confirmed by differential GPS surveys and terrestrial
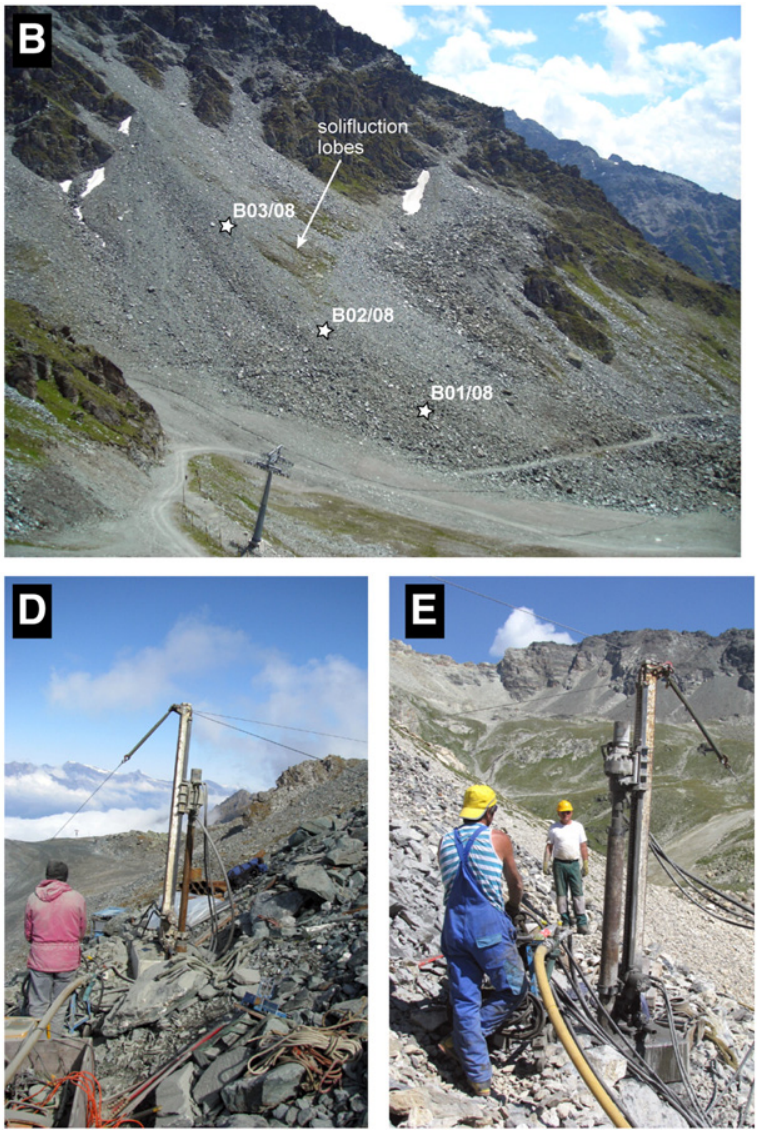

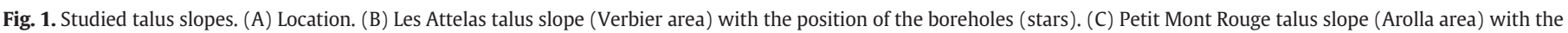

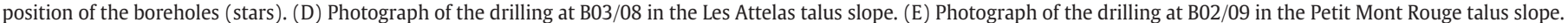



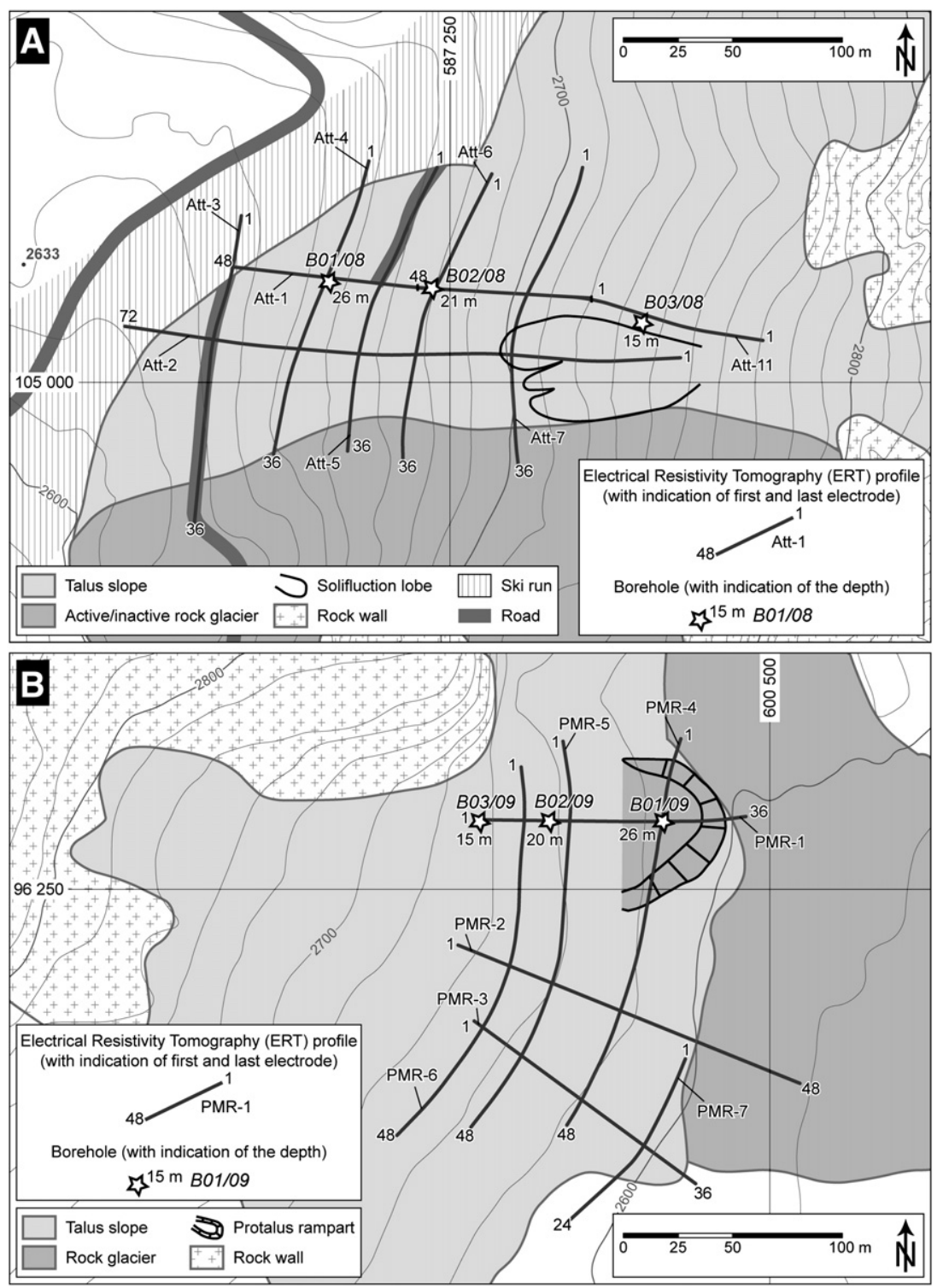

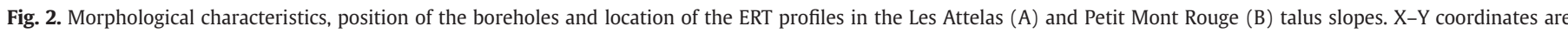
projected in Swiss Grid CH1903.

laser scanning (F. Riff and C. Lambiel, unpublished data). In the lower part of the slope, the original morphology of the talus has been disturbed by two sections of a road and by significant work carried out to level the ski runs (Fig. 2A). This work has almost entirely levelled the lowest part of the slope and the rock glaciers and morainic cover situated downslope of it. The permafrost distribution and the thermal regime of the talus slope were investigated with geoelectrical and thermal methods by Lambiel (2006) and Lambiel and Pieracci (2008), which concluded that permafrost is probably present only in the lower half of the slope. The Attelas study site is part of the Swiss permafrost monitoring network PERMOS (PERMOS, 2010).

\subsection{Petit Mont Rouge talus slope}

The Petit Mont Rouge talus slope is located on the eastern flank of the Petit Mont Rouge peak (2928 masl), at elevations comprised between 2600 and $2700 \mathrm{~m}$ (Fig. 1C). This small landform (about $200 \times 200 \mathrm{~m}$ ) is situated underneath a $200 \mathrm{~m}$ high rock wall and presents a rectilinear slope with an average angle of $31^{\circ}$. The lithology of the site is composed of metamorphic dolomites, in part alternating with limestones and marls. Debris size increases downslope, with pebbles $(<4 \mathrm{~cm})$ and sand in the upper part; small cobbles $(<10 \mathrm{~cm})$, pebbles and sand in the middle part; and very small boulders $(<24 \mathrm{~cm})$, cobbles and pebbles in the lower part. A lobate protalus rampart about $10 \mathrm{~m}$ thick with a steep (about $35^{\circ}$ ), pebbly and sandy front occupies the base of northern part of the slope. The protalus rampart surface and the lower part of the talus above it are made up exclusively of decimetre- to metre-sized boulders. Fine material and vegetation are completely absent on the protalus rampart surface and boulders are poorly covered by lichen. Differential GPS measurements showed that maximal horizontal velocities are $5-8 \mathrm{~cm} \mathrm{a}^{-1}$ (unpublished data).

The talus cone-protalus rampart sequence dominates a $220-\mathrm{m}$ long rock glacier, completely covered by alpine meadow and presenting large thermokarstic depressions, which indicate that it is probably relict. Vertical electrical soundings, apparent resistivity profiles, BTS measurements and ground surface temperature monitoring showed that the presence of frozen sediments is probable in the protalus rampart and in the lower part of the talus slope and 
improbable upslope (Delaloye and Lambiel, 2005; Lambiel, 2006; Lambiel and Pieracci, 2008).

\section{Methods}

\subsection{Borehole drilling and temperatures}

Borehole drilling is the only reliable method to determine the strata within the body of permafrost and to monitor the temporal evolution of subsurface temperatures. Many scientific boreholes have been drilled in alpine regions to study permafrost conditions, in particular within rock glaciers (e.g. Vonder Mühll, 1996; Haeberli et al., 2006), talus slopes (e.g. Delaloye, 2004; Lütschg et al., 2004), frozen moraines (e.g. Lambiel, 2006) and bedrock (e.g. Harris et al., 2003). The three main difficulties of drilling in a talus slope, where the subsurface is composed of inhomogeneous media, containing a range of materials including large boulders, pebbles, cobbles, fines and interstitial ice, are the penetration through the terrain, the removal of the drilled material (because of the changing porosity of the talus) and the stabilization of the borehole wall (cf. Mellor and Sellmann, 1975; Arenson et al., 2002).

Six boreholes were drilled for this study (Fig. 1D,E). During drilling, boreholes were flushed with chilled compressed air, and no liquids were used. When it was not necessary to stabilize the borehole wall (for the three boreholes drilled in the Les Attelas talus slope, normally from a depth of 5-6 m), the internal structure of the holes could be observed using a hand-made borehole camera. Other information about the borehole structure came from the field experience of the drilling team and from observations of the characteristics of the expulsed materials. As the boreholes were drilled destructively and not cored, it was not possible to quantify the volumetric ice content of the ground. Only a qualitative estimation (low or high content of ice) was established on the basis of the nature of the expulsed materials.

The boreholes were equipped with PVC access tubes. Chains of 12 individually calibrated thermistors (MADD Technologies Sàrl, with an accuracy of $\pm 0.1^{\circ} \mathrm{C}$ ), connected with a Multi-MADD data logger, were installed in each tube. Temperatures were measured every two hours at an increasing downhole depth interval. The data loggers were enclosed in a concrete shaft in order to protect them from rockfall, avalanches and lightning. The temperature data presented here was measured for the hydrological year 2008/2009 for the Les Attelas talus slope, and in October 2009 for the Petit Mont Rouge site.

\subsection{Electrical resistivity tomography (ERT)}

Electrical resistivity is a physical parameter which is very sensitive to the transition from unfrozen to frozen ice-rich sediments, to the increase of ice content and to the decrease of temperatures below $0{ }^{\circ} \mathrm{C}$ (Scott et al., 1990; Kneisel et al., 2008). For this reason, the application of 2D electrical resistivity tomography (ERT) in mountain permafrost studies constitutes one of the most common geophysical methods for the prospecting of alpine periglacial landforms, such as rock glaciers, talus slopes and icecored moraines (e.g. Hauck et al., 2003; Marescot et al., 2003; Hilbich et al., 2009). ERT measurements were conducted by applying an electric current into the ground, measuring its intensity with two current electrodes and measuring the resulting difference of potential with two other electrodes. The resulting apparent resistivity $\left(\rho_{\mathrm{a}}\right.$, in $\left.\Omega \mathrm{m}\right)$ was calculated by using the ratio between the difference of potential $(\Delta V)$ and the electric current $(I)$ multiplied by a k-factor that depends on the geometry of the electrode array and the topography. For a half-space, the k-factor can be evaluated analytically (Marescot et al., 2006).

The surveys were undertaken using a multi-electrode system connected to a resistivity meter, a switching unit and one to three electrode cables (with 24 electrodes per cable), depending on the length of the prospected structures. A Wenner-Schlumberger electrode array was used, with an inter-electrode spacing of $4 \mathrm{~m}$. The WennerSchlumberger array is a hybrid between the Wenner and Schlumberger arrays and is moderately sensitive to both horizontal and vertical structures (Marescot et al., 2003). Depending on the number of electrodes (24, 48 or 72), the resulting profiles are 92,188 and $284 \mathrm{~m}$ long. The current was injected into the ground using 30 to $60 \mathrm{~cm}$ steel stakes, placed as deep as possible. Where large boulders were present at the surface, sponges soaked in salt water were used in order to improve galvanic coupling. Finally, the location of the electrodes was measured with a differential GPS.

The measurements were carried out using a SYSCAL Pro Switch system (Iris Instruments). The inversion of the apparent resistivity data to reconstruct the subsurface structures was performed using the 2D inversion program RES2DINV (Loke and Barker, 1996), using a finite-element calculation for the forward problem and including the topography in the data processing using a distorted finite-element mesh (Loke, 2000). For the ERT profiles perpendicular to the slope, it was necessary to correct the depths, because the inversion results were not projected on the vertical axis but perpendicular to the slope angle. In this case, a projection of the inverted ERT profile was necessary to calculate the vertical depth of the detected layers. The projection was calculated using the equation:

$H=Z / \cos (\alpha)$

where $H(\mathrm{~m})$ is the calculated depth of the inverted ERT profile projected on the vertical axis, $Z(\mathrm{~m})$ is the depth of the inverted ERT profile and $\alpha\left(^{\circ}\right)$ is the angle between the ground surface and the horizontal axis (corresponding to the angle between the ERT inversion result and the vertical axis).

\section{Results and interpretation}

\subsection{Borehole stratigraphy}

\subsubsection{Les Attelas talus slope}

Three boreholes were drilled along an upslope-downslope transect in the Les Attelas talus slope in September 2008 (Figs. 1B and 2A). The borehole stratigraphy is presented in Fig. 3A.

Drilled in the lower part of the slope (2661 masl), the first borehole (B01/08) is $26.0 \mathrm{~m}$ in depth. The top of the ice was found below a $3.4 \mathrm{~m}$ thick unfrozen layer, composed of large boulders without matrix. Lower alternating layers of large and small loosely packed boulders and cobbles (Fig. 4) are interpreted as typical talus slope deposits. The ice content was not homogeneous; between 3.4 and $19.5 \mathrm{~m}$ in depth, six layers relatively rich in ice were observed (ice content estimated between $10 \%$ and $50 \%$ on the basis of the nature of the ejected materials - cf. Fig. 5A). A layer of granules in a massive matrix of sands and silts between 22.5 and $24.0 \mathrm{~m}$ in depth is interpreted as till. Bedrock was reached at a depth of $24.0 \mathrm{~m}$.

Borehole B02/08 was drilled in the middle of the slope (2689 masl) and is $21.0 \mathrm{~m}$ deep. Below a $4.5 \mathrm{~m}$ thick unfrozen layer, composed of boulders without matrix, $13.5 \mathrm{~m}$ of ice-rock mixture was present (Fig. 4). This section was composed of alternating layers of small boulders and cobbles, loosely packed, with at least four layers relatively rich in ice (ice content estimated about $20 \%$ ). The bedrock was located at a depth of $18.0 \mathrm{~m}$.

In borehole B03/08 (15.2 $\mathrm{m}$ deep), which was drilled in the upper part of the talus slope at an altitude of 2741 masl, the sediments were not frozen (Fig. 4). Below a $2.9 \mathrm{~m}$ thick surface layer, composed of boulders and cobbles without matrix, a $5.5 \mathrm{~m}$ thick less porous layer was found. This layer was composed of clast-supported small boulders and cobbles, with a compacted matrix of granules and sands. A layer of porous sediments, composed of boulders and cobbles in a loose matrix, was reached between 7.5 and $15.2 \mathrm{~m}$ in depth. Bedrock was not reached. 
A

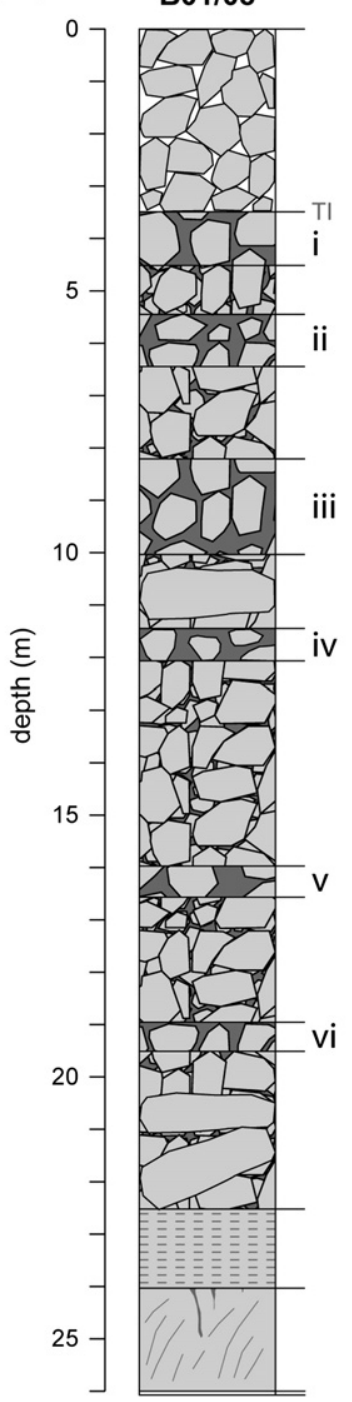

B02/08

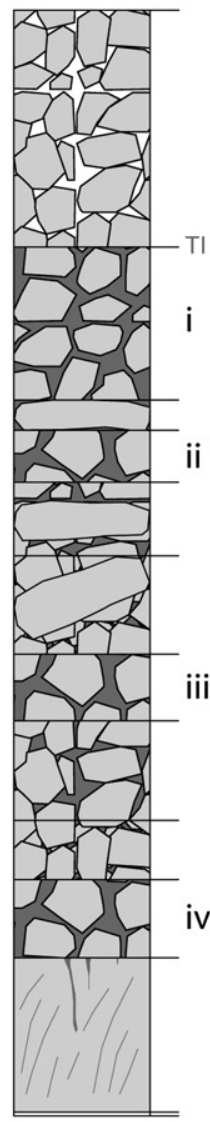

B03/08

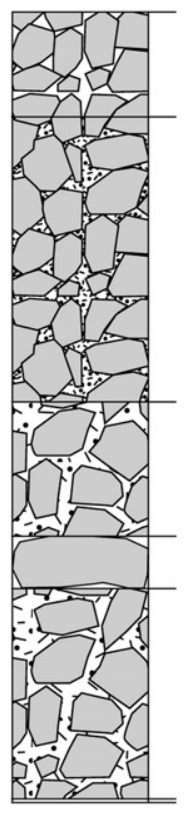

$\mathrm{TI}=$ top of the ice

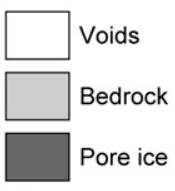

Large boulder

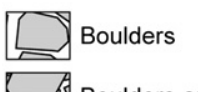

Bould

Boulders and cobbles

$\because-1 .-$ Pebbles, granules and sands (loose)

Pebbles, granules and sands (compacted)
B Temperature $\left({ }^{\circ} \mathrm{C}\right)$

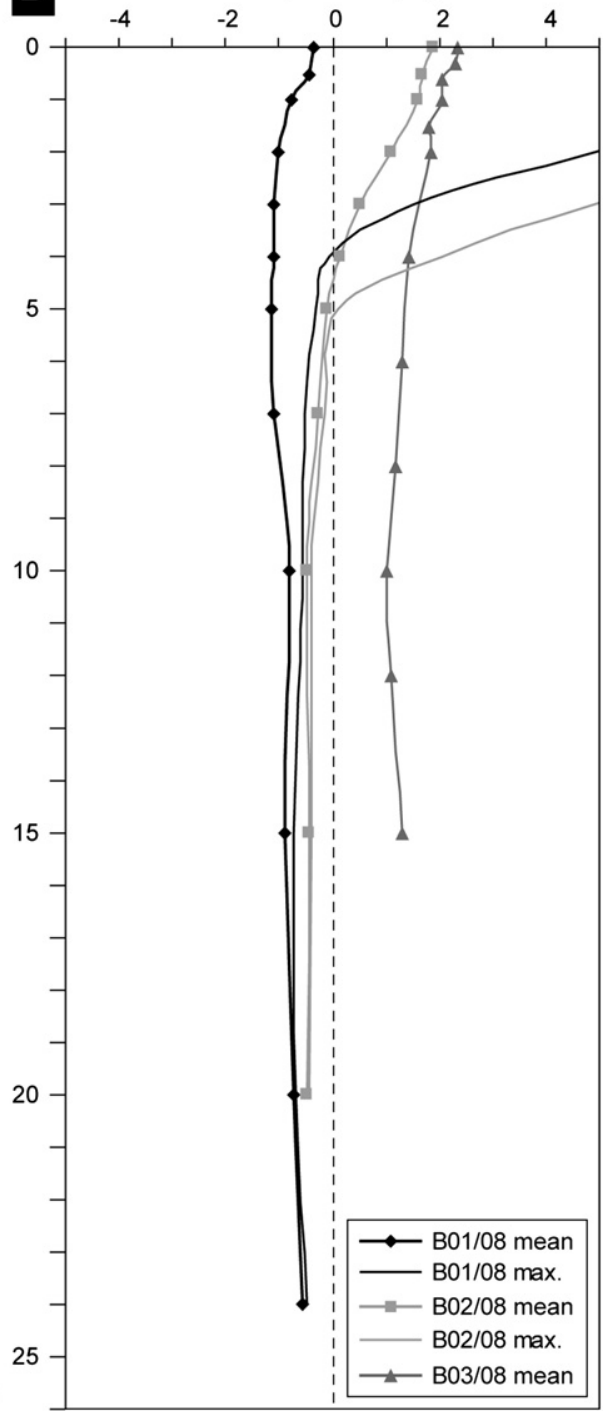

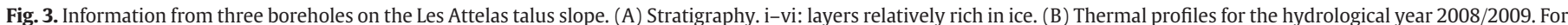
the position of the boreholes, see Figs. 1B and 2A.

\subsubsection{Petit Mont Rouge talus slope}

In the Petit Mont Rouge talus slope, three boreholes were drilled in August 2009 along an upslope-downslope profile in the northern part of the talus (Figs. 1C and 2B). The stratigraphy of the boreholes is presented in Fig. 6A.

The lowest borehole (B01/09) was drilled on the protalus rampart (2608 masl) and is $26.0 \mathrm{~m}$ in depth. Unfrozen sediments, with boulders and cobbles without matrix, compose the first $4.0 \mathrm{~m}$. The top of the frozen sediments was reached at a depth of $4.0 \mathrm{~m}$. Between $4.0 \mathrm{~m}$ and $18.0 \mathrm{~m}$, a relatively homogeneous layer is composed of cobbles and pebbles in a massive matrix of granules and sands and without indices of stratification. The pores were filled with ice. Below the base of the frozen sediments, which was reached at a depth of $18.0 \mathrm{~m}$, a very porous layer was present, composed of cobbles and pebbles without matrix.

Borehole B02/09 was drilled in the middle of the slope (2635 masl) and is $23.0 \mathrm{~m}$ deep. Because of the instability of the borehole walls, fallen materials filled the last $3 \mathrm{~m}$ of the borehole. In consequence, the depth reached by the PVC access tube was only $20.5 \mathrm{~m}$. Below a $3.0 \mathrm{~m}$ thick surface layer, composed of small boulders and cobbles in a pebbly matrix, $14.0 \mathrm{~m}$ of cobbles and pebbles in a compacted matrix of granules and sands without indices of stratification were observed, with pore ice between 8.0 and $15.5 \mathrm{~m}$ in depth. Below $17.0 \mathrm{~m}$ in depth, the talus slope deposits were more porous, with cobbles and pebbles without matrix.

No ice was encountered in the $15.0 \mathrm{~m}$ deep borehole drilled in the upper part of the talus slope (2659 masl). Below a surface layer of boulders and cobbles, a $3.0 \mathrm{~m}$ thick layer composed of compacted pebbles, granules and sands was found (Fig. 5B). The layer between 3.0 and $15.0 \mathrm{~m}$ in depth was less porous and was composed of very humid compacted granules and sands, without indices of stratification. In the three boreholes, the bedrock was not reached.

\subsection{Borehole temperature}

\subsubsection{Les Attelas talus slope}

The thermal profiles presented in Fig. 3B correspond to the hydrological year 2008/2009: the difference in the temperature regime between the three boreholes is evident. Mean annual ground temperatures measured in the lowest boreholes (B01/08 and B02/08) were permanently negative below a seasonally frozen layer, indicating the presence of permafrost and showing that the permafrost base was not reached. The borehole situated in the upper part of the slope 


\section{B01/08}
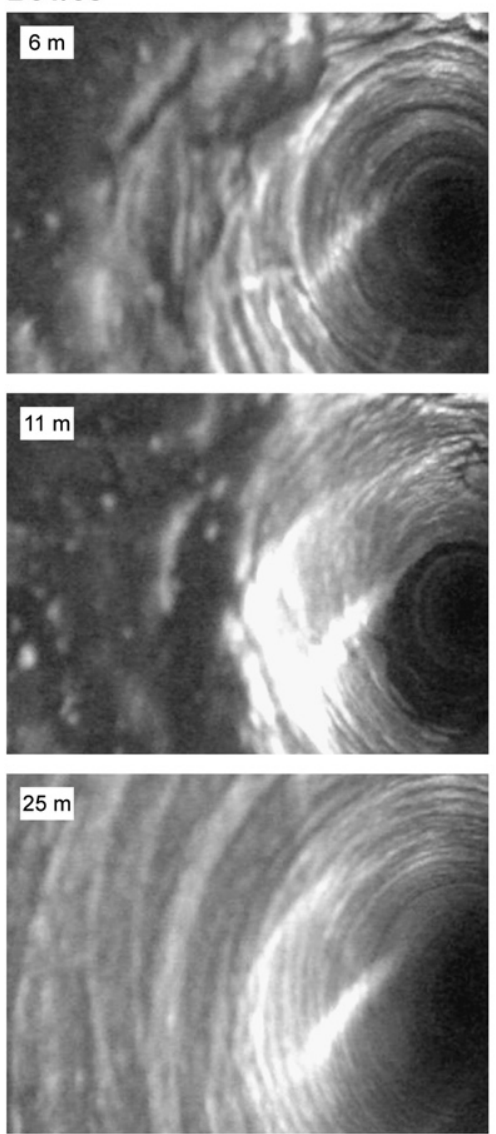

\section{B02/08}
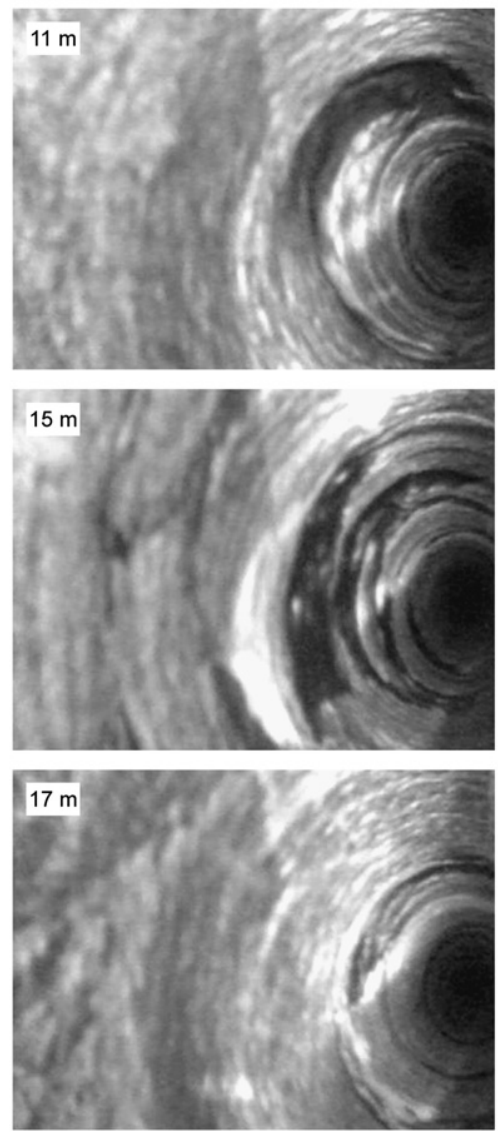

B03/08
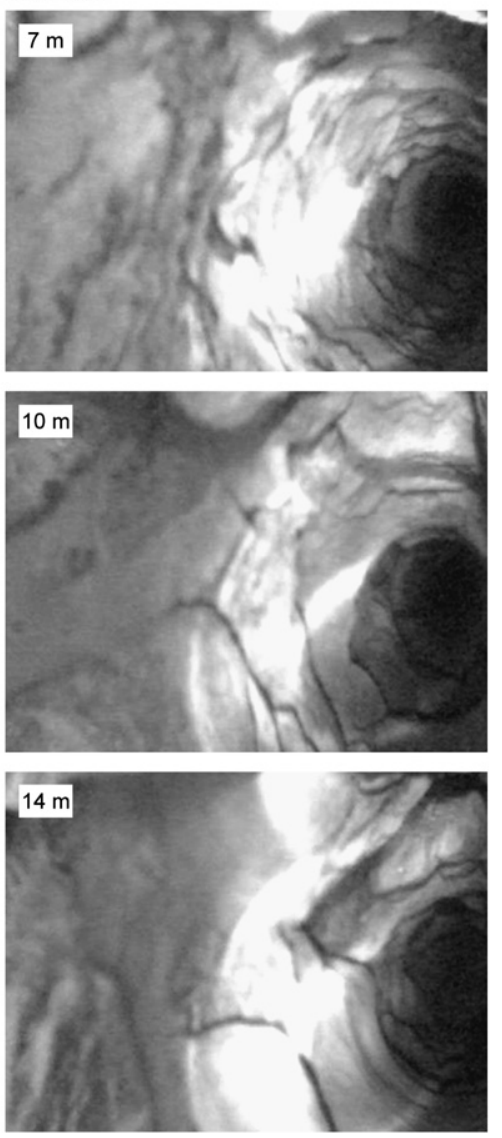

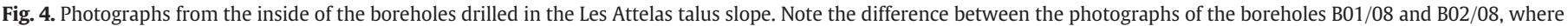
frozen sediments are present, and those of the borehole B03/08, where ice is absent.

(B03/08) showed positive mean annual ground temperatures at all depths, indicating the absence of permafrost. The active layer thickness could be defined thanks to the annual maximal values (B01/08 max. and B02/08 max. curves in Fig. 3B), and corresponds to $3.8 \mathrm{~m}$ and $5.0 \mathrm{~m}$, respectively. Mean annual minimum temperatures $\left(-1.1^{\circ} \mathrm{C}\right)$ were situated at a depth of $5.0 \mathrm{~m}$ for B01/08. B02/08 was slightly warmer than $\mathrm{B} 01 / 08$, with a mean annual minimum temperature of about $-0.5{ }^{\circ} \mathrm{C}$ between 10.0 and $20.0 \mathrm{~m}$ depth, whereas the temperatures recorded in B03/08 were widely positive, with a mean annual minimum temperature of $+1.0{ }^{\circ} \mathrm{C}$ at a depth of $10.0 \mathrm{~m}$.

\subsubsection{Petit Mont Rouge talus slope}

At the Petit Mont Rouge talus slope, temperatures only for the period between 22 and 29 October 2009 are available. The thermal contrast between the upper and lower parts of the slope is very strong (Fig. 6B). The two lowest boreholes (B01/09 and B02/09) show negative values below a depth of 5.0 and $10.0 \mathrm{~m}$, respectively. It is
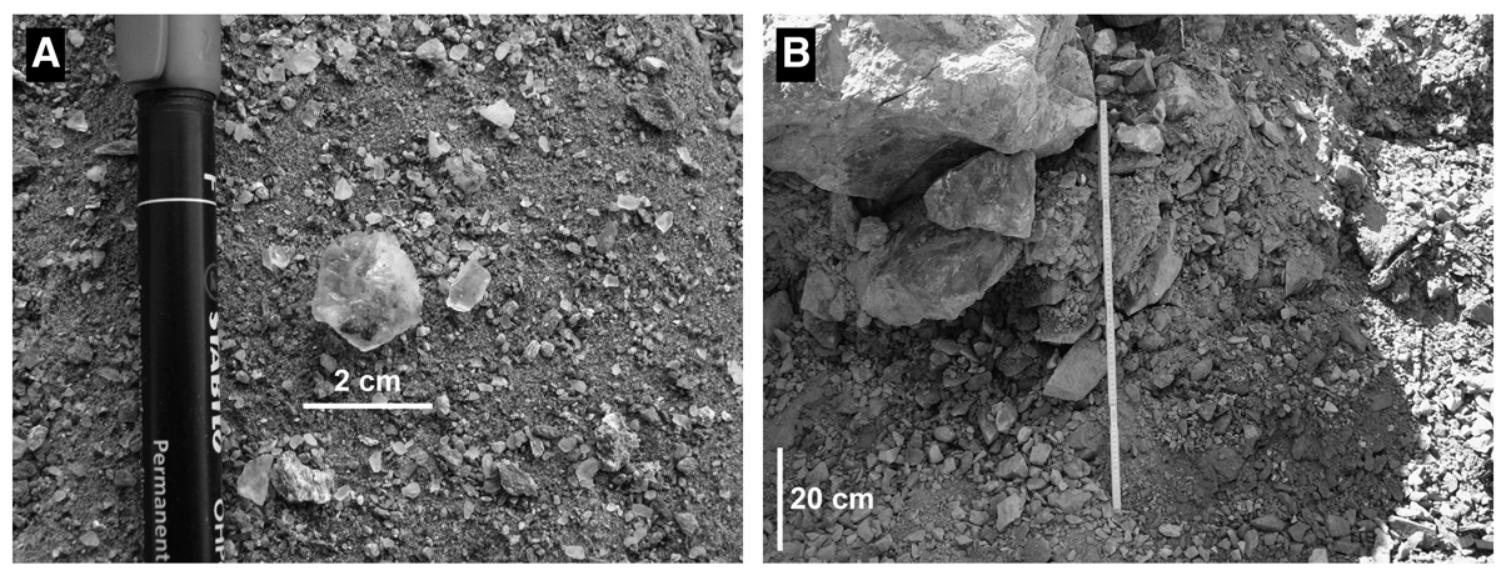

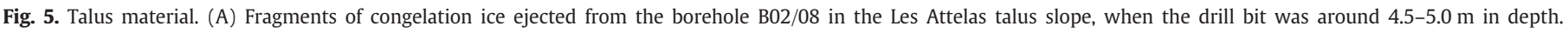

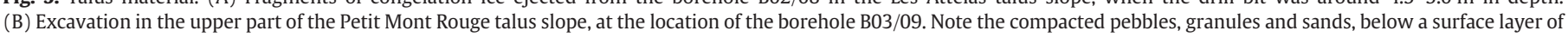
boulders and cobbles. 

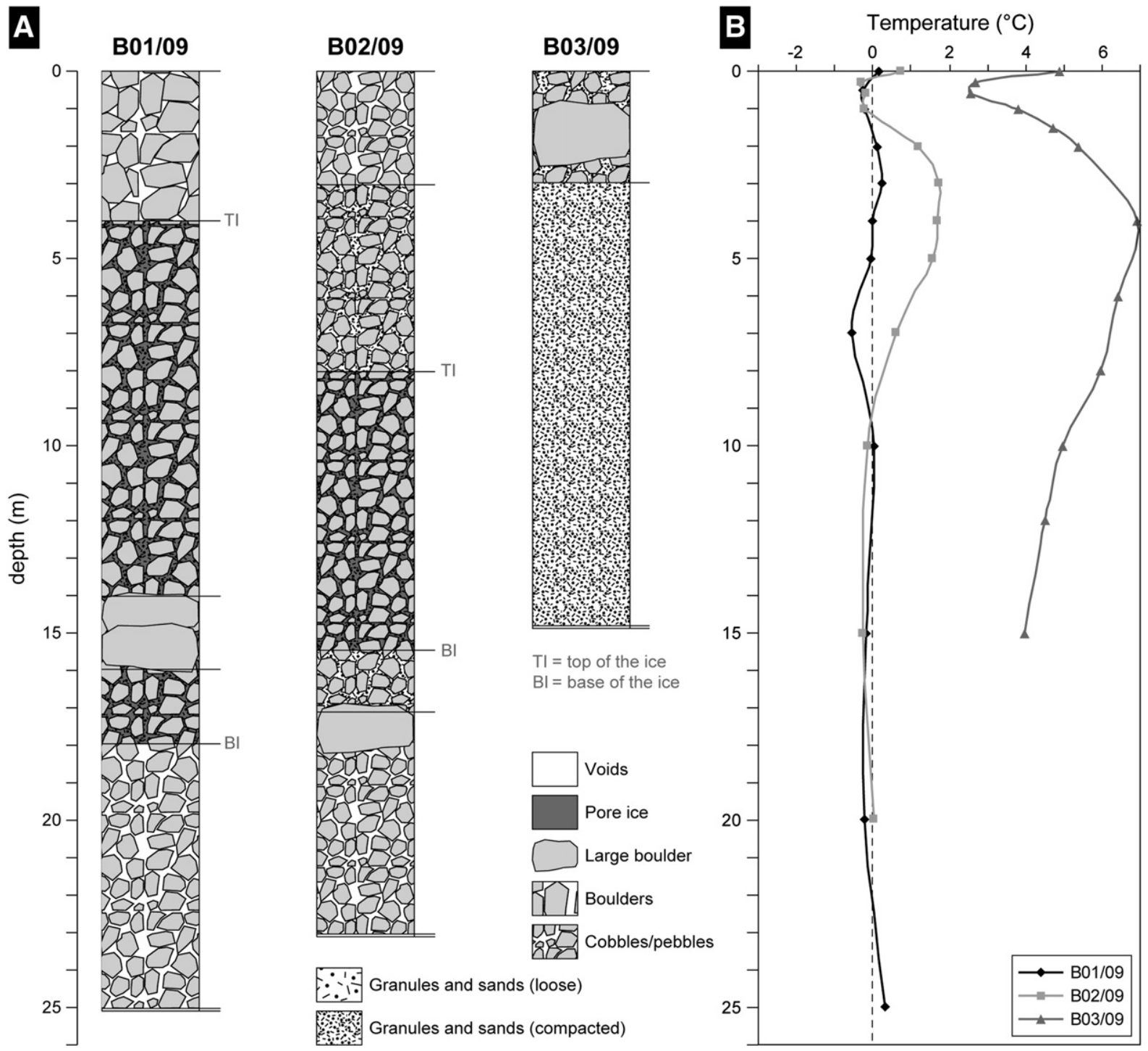

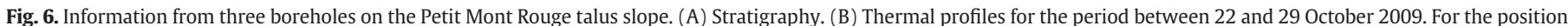
of the boreholes, see Figs. 1C and 2B.

worthwhile noting that the temperature significantly exceeded $0{ }^{\circ} \mathrm{C}$ at $10.0 \mathrm{~m}$ depth in B01/09 $\left(+0.1^{\circ} \mathrm{C}\right)$. The coldest temperatures were measured at a depth of $7.0 \mathrm{~m}\left(-0.5^{\circ} \mathrm{C}\right)$ for B01/09 and at a depth of $15.0 \mathrm{~m}\left(-0.2^{\circ} \mathrm{C}\right)$ for B02/09. The base of the frozen layer was reached between 20.0 and $25.0 \mathrm{~m}$ in depth in B01/09, and between 15.0 and $20.0 \mathrm{~m}$ in depth in B02/09. The borehole in the upper part of the slope (B03/09) showed positive temperatures throughout the measurement period, with a maximal value of $+6.9{ }^{\circ} \mathrm{C}$ at a depth of $4.0 \mathrm{~m}$, indicating the absence of perennially frozen sediment.

\subsection{Electrical resistivity tomography (ERT)}

\subsubsection{Les Attelas talus slope}

Eight ERT profiles were performed on the Les Attelas talus slope in summer 2009 (Fig. 2A). Three profiles (Att-1, Att-2 and Att-11) were measured on an upslope-downslope transect, between the ski run at the foot of the slope and the upper part of the talus slope, above the solifluction lobes. Note that Att-1 and Att11 are aligned along the same profile to cover a longer distance. The transect covered by the profiles Att-1 and Att-11 crosses the three boreholes. Five other horizontal ERT profiles, perpendicular to the slope, cross the upslope- downslope profiles. They cross the whole talus slope and were carried out in the lower half of the slope in order to determine the lateral extension of the prospected structures.

The upslope-downslope profiles (Fig. 7- for simplicity, the profiles Att- 1 and Att-11, that cross it on 24 electrodes, were inverted jointly in the profile Att-11/1) show a difference in resistivities between the lower and upper parts of the talus slope. A 15-20 m thick resistive body with values higher than $15 \mathrm{k} \Omega \mathrm{m}$ (with maximal resistivities higher than $50 \mathrm{k} \Omega \mathrm{m}$ ) is present in the lower part of the slope, with resistivities decreasing upslope. According to the stratigraphy and temperatures of the boreholes B01/08 and B02/08 (Fig. 3A), this resistive body can be interpreted as a permafrost lens. Below this layer, resistivities decrease to $2-10 \mathrm{k} \Omega \mathrm{m}$, indicating that bedrock or unfrozen sediments were encountered (according to Lambiel (2006), micaschists of the Verbier area have a resistivity of 5$8.5 \mathrm{k} \Omega \mathrm{m}$ ). In the central part of the profile Att- $11 / 1$ a $5-10 \mathrm{~m}$ thick layer with lower resistivities ( $<5 \mathrm{k} \Omega \mathrm{m}$ ) is superimposed on a resistive body $(10-15 \mathrm{k} \Omega \mathrm{m})$ found at greater depth (Fig. 7). This second resistive body can be interpreted either as low-resistivity permafrost or as porous sediment. Finally, the uppermost part of the profiles present homogeneous resistivities lower than $5 \mathrm{k} \Omega \mathrm{m}$ indicating the 

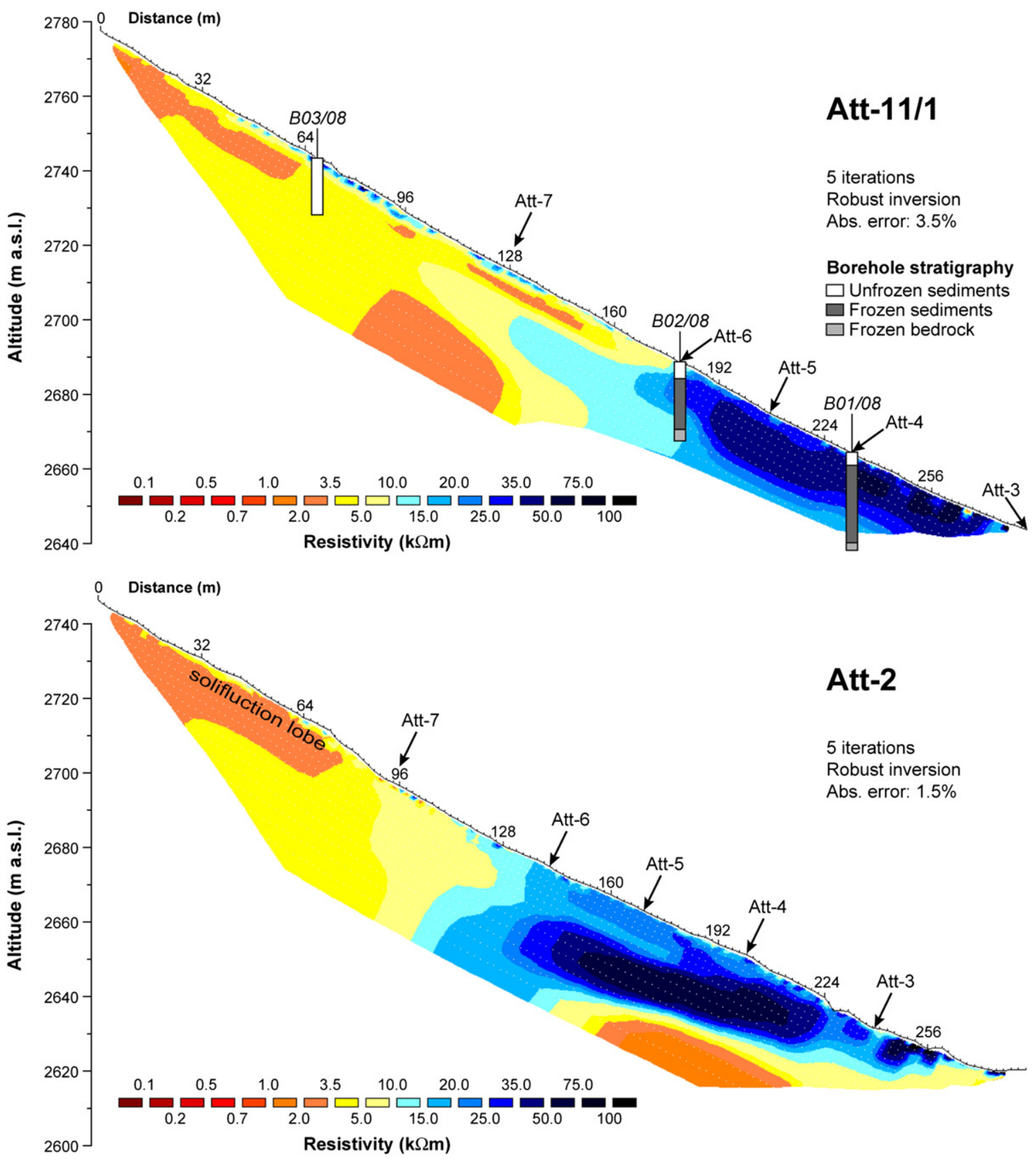

Fig. 7. Upslope-downslope ERT inverted profiles on the Les Attelas talus slope. Boreholes with simplified stratigraphy are superimposed on the Att-11/1 inverted profile.

absence of frozen sediments, which corresponds to the stratigraphy and the temperature of the borehole B03/08. The same conclusion can be drawn for the Att-2 profile.

The lowest horizontal profile (Att-3 -Fig. 8) presents a body of frozen sediments with resistivities higher than $15 \mathrm{k} \Omega \mathrm{m}$ and a thickness of about $10-15 \mathrm{~m}$ between 30 and $76 \mathrm{~m}$ of distance. It corresponds to the lower part of the permafrost lens present in the profile Att-2. Under and around it, resistivities lower than $5 \mathrm{k} \Omega \mathrm{m}$ indicate the absence of frozen sediments, as in the lowest part of the profile Att-11/1. The body of frozen sediments becomes larger upslope, at the altitude of the borehole B01/08, as shown in the profile Att-4 (Fig. 8). The only zone without frozen sediments is present in the first part of the profile, corresponding to the ski run. At the level of the profile Att-2, a small decrease of resistivities (with values ranging between 20 and $35 \mathrm{k} \Omega \mathrm{m}$ ) is interpreted as a transition between the permafrost lens at the emplacement of the borehole B01/08 and another permafrost lens at the end of the profiles, which would correspond to the active/inactive rock glacier situated in the southern part of the slope (Fig. 2A). The same configuration is present in the profile Att-5 (Fig. 8). The transition zone between the resistive body in the area of the profile Att-11/1 and the active/inactive rock glacier presents resistivities ranging between 15 and $35 \mathrm{k} \Omega \mathrm{m}$. An important difference is visible in the resistivities measured in the profiles Att-2 (Fig. 7) and Att-5 at the same location. This difference is probably due to the fact that the profile Att- 2 was carried out in the transition zone between two more resistive bodies (lateral effect). The 2D ERT data inversion processing supposes that there are no changes in resistivities perpendicular to the profile, which is obviously not the case for the profile Att- 2 . The inversion process probably considered the two resistive bodies as continuous. The profile Att-6 (Fig. 8) shows 

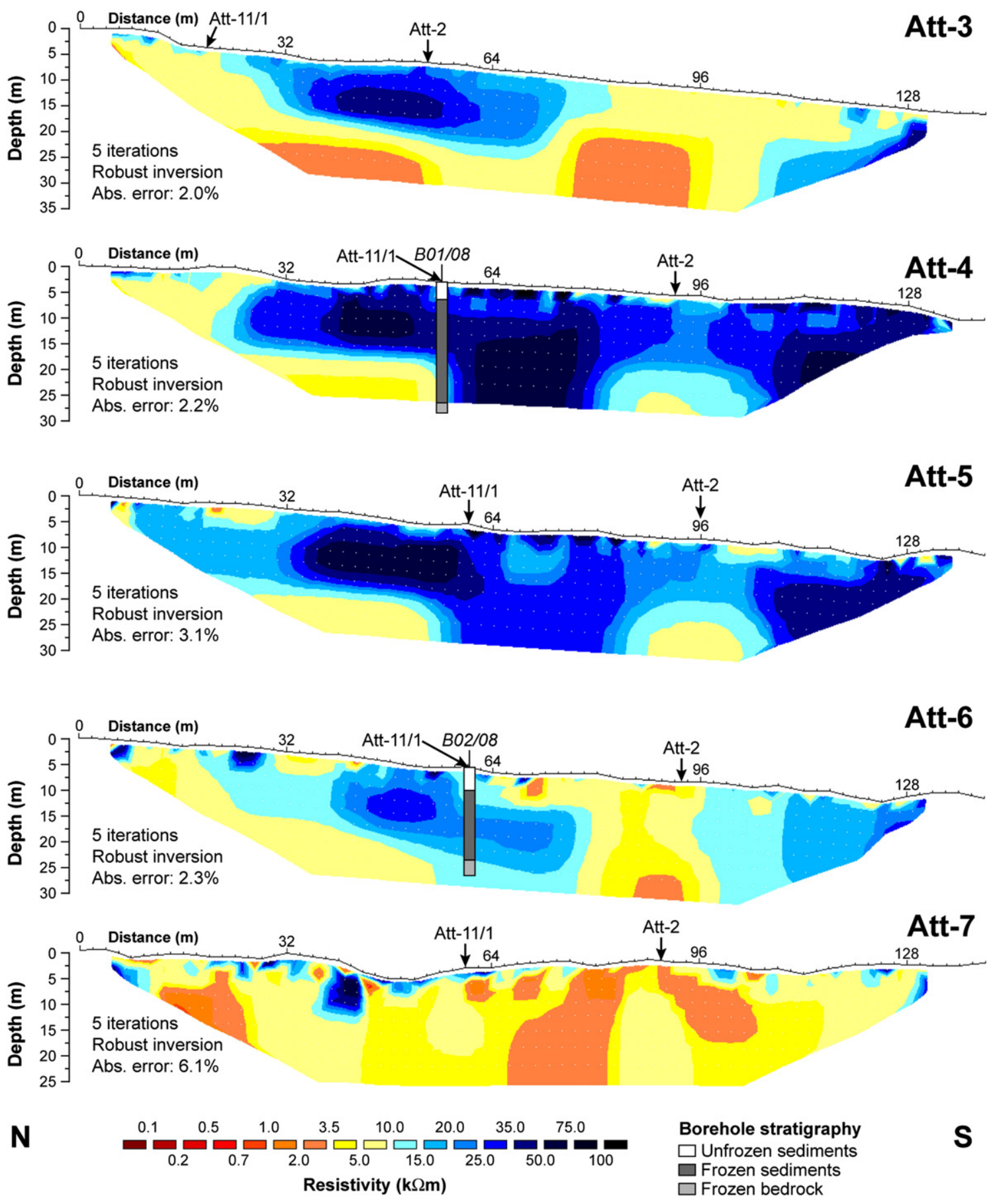

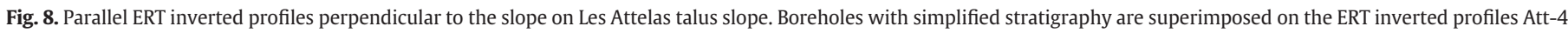
and Att-6. The depth of the ERT profiles was corrected based on Eq. (1).

decreasing resitivities of the frozen body. Below the borehole B02/08 there is a good correspondence between the resistivities measured in the profiles Att-11/1 and Att-6, whereas a marked difference exists with the values measured in the profile Att-2 (Fig. 7). The lateral heterogeneity observed on the profile Att- 5 is also visible here. Since this feature is consistent through the Att- 3 to Att- 6 profiles, we suspect the existence of two ice bodies. Finally, the upper profile (Att-7 -Fig. 8) presents relatively low resistivities ( 1 to $10 \mathrm{k} \Omega \mathrm{m}$ ) indicating the absence of frozen sediments, which corresponds to the resistivities measured in the profiles Att-11/1 and Att- 2 at the same location (Fig. 7).

\subsubsection{Petit Mont Rouge talus slope}

In summer 2009, seven ERT profiles were carried out on the Petit Mont Rouge talus slope (Fig. 2B). Three parallel profiles were performed on an upslope-downslope transect. The profile PMR-1 is situated in the northern part of the slope, and crosses the protalus rampart and the three boreholes, whereas the profiles PMR-2 and PMR-3 are situated, respectively, in the central and in southern parts of the slope. Four other parallel ERT profiles totally or partially cross the upslope-downslope profiles.

The three upslope-downslope profiles (Fig. 9) show a difference in resitivities between the upper and lower sections of the talus slope 


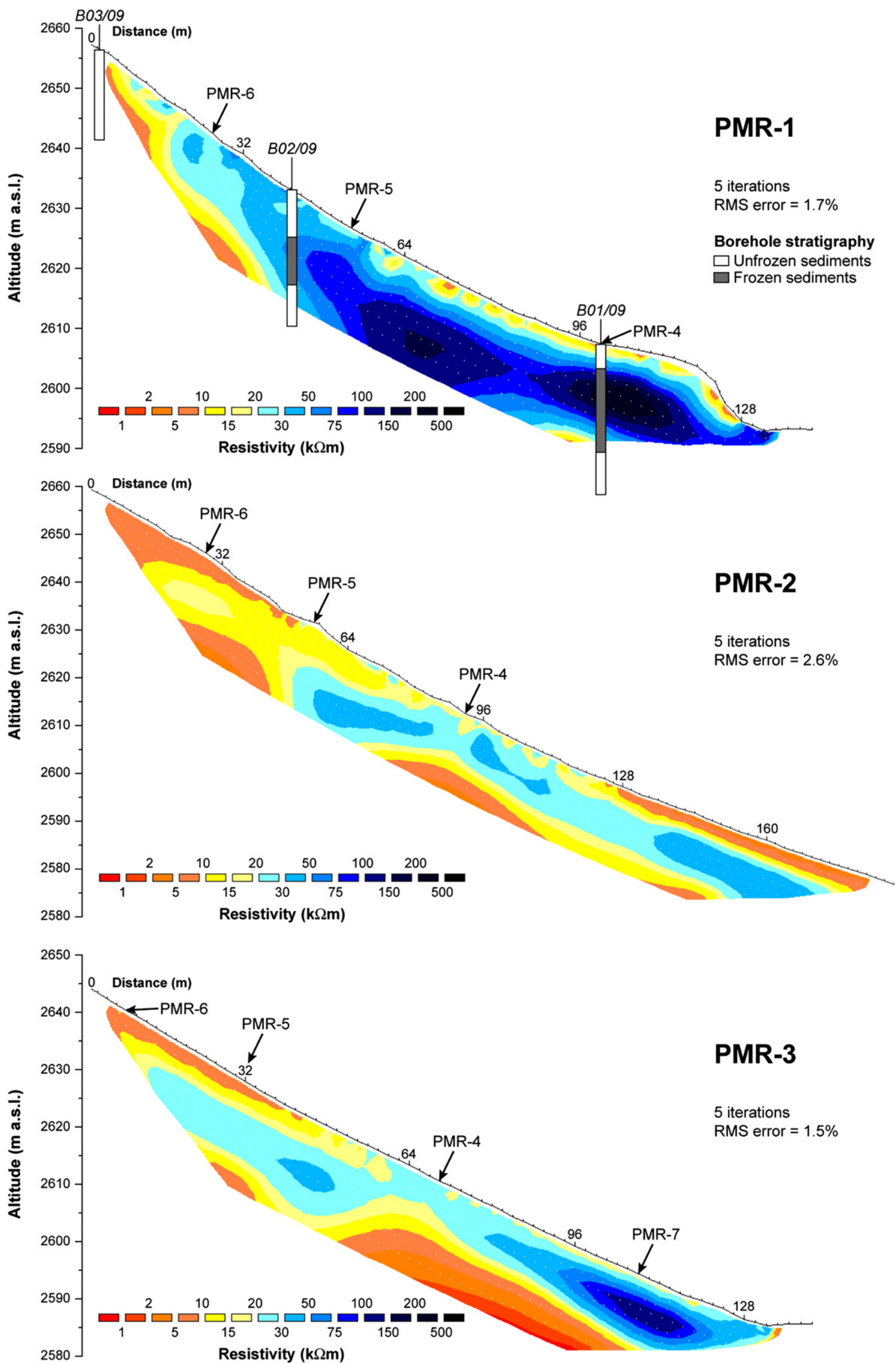

Fig. 9. Upslope-downslope ERT inverted profiles on the Petit Mont Rouge talus slope. Boreholes with simplified stratigraphy are superimposed on the PMR-1 inverted profile. 
and between the borders and the central part. The maximal resitivities are higher than $200 \mathrm{k} \Omega \mathrm{m}$ in the protalus rampart (profile PMR-1), lower than $50 \mathrm{k} \Omega \mathrm{m}$ in the central and lower parts of the profile PMR-2 and comprised between 150 and $200 \mathrm{k} \Omega \mathrm{m}$ in the lower part of the profile PMR-3 (Fig. 9). According to the stratigraphies and the temperatures of the three boreholes (Figs. 6A and 9), resitivities higher than $50 \mathrm{k} \Omega \mathrm{m}$ and lower than $20 \mathrm{k} \Omega \mathrm{m}$ correspond respectively to the presence and absence of frozen sediments. For resistivities ranging between 20 and $50 \mathrm{k} \Omega \mathrm{m}$, it is very difficult to separate unfrozen porous sediments from frozen sediments with temperate ice. As the dolomites and limestones of the Arolla area have a resistivity of about $8 \mathrm{k} \Omega \mathrm{m}$ (Lambiel, 2006), it is also very difficult to distinguish the bedrock from the unfrozen sediments. According to these considerations, the large resistive body between the borehole B02/09 and the protalus rampart in the profile PMR-1, and the resistive body in the lower part of the profile PMR-3 (between a distance of 92 and $122 \mathrm{~m}$ ) can be interpreted as a permafrost lens. For the profile PMR-1, the inverted resistivities (Fig. 9) show the presence of two bodies, probably connected, of ice-rich sediments in the lower part of the talus slope (between 54 and $82 \mathrm{~m}$ ) and in the protalus rampart (between 88 and $116 \mathrm{~m}$ ). According to the morphology of the protalus rampart (steep and unstable front) and high resistivities, the sediments in the protalus rampart are probably saturated or supersaturated with ice. The resistive body in the profile PMR-2 can either be interpreted as porous sediment, very-low-resistivity permafrost or an artefact due to the lateral effect related to the position of the other resistive bodies north and south of the profile, as can be seen in a consistent way on the profiles PMR-5 and PMR-6.

The four parallel ERT profiles perpendicular to the slope corroborate the geometry of the prospected structures. The profile PMR-4 (Fig. 10) presents a discontinuous body of frozen sediments with resistivities higher than $50 \mathrm{k} \Omega \mathrm{m}$ and a maximal thickness of about 10 $15 \mathrm{~m}$ up to $118 \mathrm{~m}$ of distance. Where the profile crosses the profiles
PMR-2 and PMR-3, frozen sediments are probably absent. At the profile PMR-5 (Fig. 10), resistivities higher than $50 \mathrm{k} \Omega \mathrm{m}$, indicating the presence of permafrost, are present only in the first part of the profile, between 10 and $52 \mathrm{~m}$ of distance. Another high resistivity anomaly is visible between 56 and $66 \mathrm{~m}$ of distance. Resistivities between 20 and $50 \mathrm{k} \Omega \mathrm{m}$ indicate the possible presence of permafrost. The upper profile (PMR-6 -Fig. 10) presents relatively low resistivities (5 to $20 \mathrm{k} \Omega \mathrm{m}$ ), indicating the probable absence of frozen sediments. Finally, the short 24 electrode profile in the lower part of the talus slope (PMR-7 -Fig. 10) confirms the resistivities and the geometry of the permafrost body detected in the lower part of the profile PMR-3.

\section{Discussion}

\subsection{Permafrost distribution}

The comparison between the borehole data (observations, stratigraphy and thermal profiles) and the ERT inverted profiles allows the stratigraphy of the talus slopes to be validated, both for the distribution of frozen sediments and for the depth of the detected structures (cf. Figs. 7 to 10). For the two study sites, both borehole stratigraphies/temperatures and ERT data present an important contrast in permafrost distribution between the lower and upper parts of the talus slopes. The coldest borehole temperatures and the highest resistivities were measured in the lower part of the slopes, indicating that permafrost is present. In both sites, the resistivities decrease, the borehole temperatures get warmer and the active layer thickness increases upslope, indicating a warming of permafrost and/ or a decrease in ice content. Finally, in the upper part of both talus slopes, borehole temperatures are positive and resistivities are the lowest, indicating the absence of permafrost at depth. The interpretation of ERT inverted profiles based on borehole stratigraphies and temperatures allow the lateral extension of permafrost to be
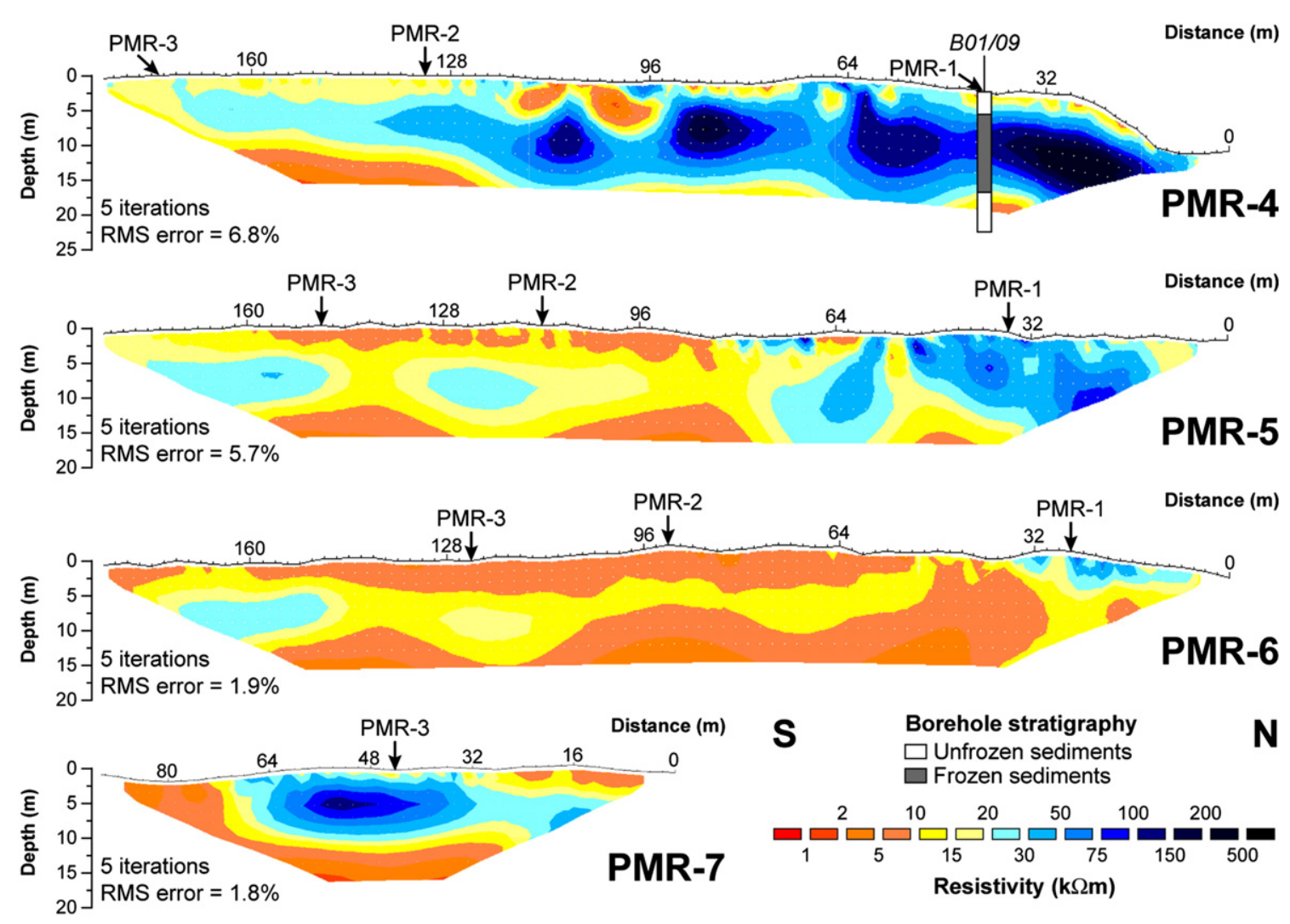

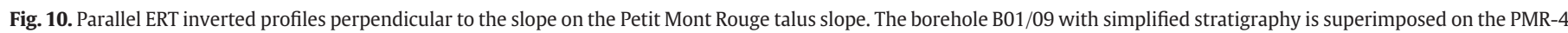
inverted profile. The depth of the ERT profiles was corrected based on Eq. (1). 
determined. A synthesis of the permafrost distribution in the Les Attelas and Petit Mont Rouge talus slopes is presented in Fig. 11.

On the basis of all the observations and measurements carried out, it is possible to conclude that, in both sites, permafrost is present in the lower sections of the talus slope, whereas it is absent in the upper parts. The same conclusion was obtained in the Lapires talus slope, situated $1.5 \mathrm{~km}$ north of the Les Attelas site and also studied using borehole temperatures and ERT data (Scapozza et al., 2010a). These results are also in accordance with the pioneer work of Haeberli (1975) and the more recent studies carried out on other alpine periglacial talus slopes (e.g. Lerjen et al., 2003; Lütschg et al., 2004; Delaloye and Lambiel, 2005; Otto and Sass, 2006; Lambiel and Pieracci, 2008; Pieracci et al. 2008; Scapozza et al., 2011). Unfortunately, because no measurements could be made in the uppermost part of the study sites, it was not possible to determine if permafrost is present in the upper sections of the talus, as was observed by Lambiel and Pieracci (2008) in other sites.

Due to the restricted drilling possibilities, only a few verifications of permafrost distribution models by direct in situ measurements and observations have been carried out in periglacial talus slopes. The data presented by Lütschg et al. (2004) and Phillips et al. (2009) for the Flüela Pass focuses on the lower and upper parts of the slope, but direct data of the transition zone between frozen and unfrozen sediments (generally the middle part of the slope) is not available. Since our data confirms the indirect measurements carried out on many other sites (see references above) by direct verification, the model of permafrost distribution in alpine periglacial talus slopes can be up-scaled to the regional scale. This up-scaling could be of particular interest for permafrost distribution modelling. In fact, the particular behaviour of permafrost distribution in periglacial talus slopes has never been considered in alpine permafrost distribution models, despite several models having been produced for a subregional spatial scale. In all these models, the permafrost probability increases upslope (e.g. Hoelzle et al., 2001; Guglielmin et al., 2003; Riseborough et al., 2008), which is in contradiction to the data shown here.

Resistivity values are different from one site to another, and for the Petit Mont Rouge talus slope, between the northern and southern parts of the slope. These differences can be due, on the one hand, to the greater porosity of the Petit Mont Rouge talus slope, related to the lithology composed of dolomites and limestones, and favourable to chemical dissolution (kastification), and on the other hand, to a difference in ice content and temperature. Where no creeping landforms are present, maximal resistivities are comprised between 75 and $150 \mathrm{k} \Omega \mathrm{m}$ (ERT profiles Att-1, Att-2, and PMR-3). These values, as with the rectilinear surface topography, indicate that the lower parts of the talus slopes are probably undersaturated or, at the most, saturated in ice. Where a landform of creeping permafrost is present, on the other hand, maximal resistivities are higher than $200 \mathrm{k} \Omega \mathrm{m}$ (for instance on the protalus rampart in the Petit Mont Rouge site), indicating that the lower part of the slope is probably saturated or supersaturated in ice. Nevertheless, the protalus rampart in the Petit Mont Rouge talus slope is probably not completely (super)saturated in ice: the positive temperatures registered at a depth of $10 \mathrm{~m}$ in the borehole B01/09 (Fig. 6B) may indicate the presence of a talik, probably due to intrapermafrost groundwater or air flow (cf. Vonder Mühll, 1992; Phillips et al., 2009).

\subsection{Talus slope structure}

The stratigraphy recorded in the boreholes shows that the Les Attelas talus slope is probably stratified, whereas no indices of stratification could be observed in the Petit Mont Rouge talus slope. Indices of stratification for the Les Attelas site are present only in the two lower boreholes (B01/08 and B02/08). Stratified talus slopes are generally due to an alternation of different processes and/or changes in intensity of rockfall generation (e.g. Francou, 1988; van Steijn et al. 2002; Sass and Krautblatter, 2007), with layers of angular rock fragments embedded in a finer matrix alternating with layers of equally angular material with an openwork structure. For Sass and Krautblatter (2007), in warm temperate conditions this alternation may correspond to climatic oscillations during the Lateglacial and the Holocene, with an important delivery of coarse debris in cold periods of freeze-thaw activity (e.g. Little Ice Age), and the depletion of finergrained intermediates stores connected with summer rainstorms in warmer periods like today.

The Les Attelas talus slope is not a typical stratified talus slope, but a pseudo-stratified talus slope (Francou and Hétu, 1989) with alternating layers of ice-rich coarse debris and ice-poor finer debris. This pseudo-stratified structure has been also confirmed by borehole geophysics, with natural gamma-ray and induced gamma-gamma and neutron-neutron methods performed in summer 2009 (Scapozza et al., 2010b). According to Haeberli and Vonder Mühll (1996), the pseudo-stratification is probably due to an inhomogeneous aggradation of congelation ice over time, which is built in contact with the permafrost table, and to the incorporation of the resulting ice-rich layer at a greater depth by aggradation of the talus slope over time. In Les Attelas, the presence of ice-rich coarse debris may correspond to extended cold phases, when the negative heat balance at the ground surface allowed the aggradation of congelation ice at the base of the active layer in the lower section of the talus slope (French, 1996; Haeberli and Vonder Mühll, 1996). In transition periods between cold and warm climatic oscillations, a rise in MAAT induces a rise in the position of the "zone of maximal rockfall generation". According to
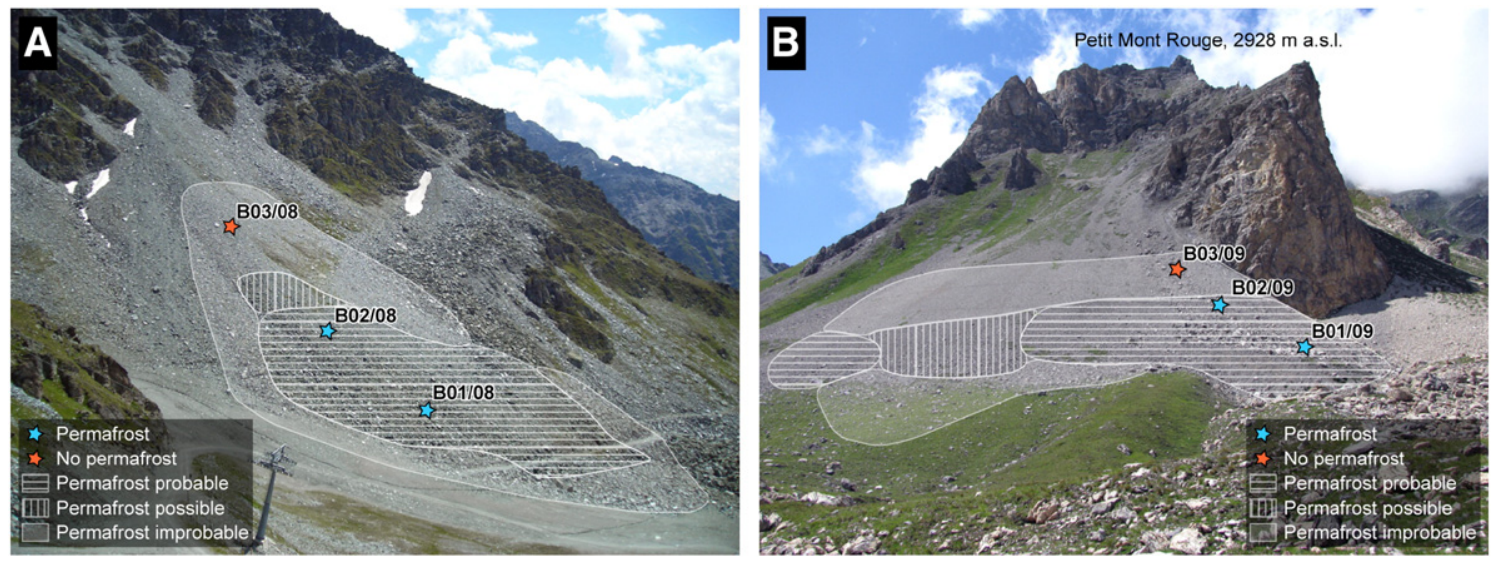

Fig. 11. Synthesis of the permafrost distribution in the Les Attelas (A) and Petit Mont Rouge (B) talus slopes. 
Davies et al. (2001), the stability of a rock wall with ice-filled joints is minimal at a temperature of $-0.5^{\circ} \mathrm{C}$, with a safety factor that passes below 1 (considered as the limit between stability and instability). Considering that these altitudinal fluctuations of MAAT during the Lateglacial and Holocene climatic oscillations probably corresponded to altitudinal fluctuations of the safety factor, with a greater production of debris when the temperature of the rock wall rose above $-1.0^{\circ} \mathrm{C}$. This particular zone with a mean annual rock temperature (MART) of about $-0.5{ }^{\circ} \mathrm{C}$ corresponds to a "zone of maximal rockfall generation".

During periods of high rockfall generation, a part or the whole active layer could be incorporated in the permafrost body, because of increasing thickness of the uppermost layers due to frequent rockfalls, characterised by the deposit of coarse debris at the surface of the talus slopes. In addition, the rockfall activity could incorporate seasonal snow, avalanche deposits or perennial snow banks that could have persisted at the surface of the talus into the permafrost.

The ice-poor debris, on the other hand, may result from warmer phases with lower rockfall activity, when, according to Davies et al. (2001), certain slopes containing discontinuities may be considered stable because of the disappearance of ice. These warm periods are characterised by an interruption of the aggradation of ice within the lower part of the talus slopes and by a more intense activity of debris flows due to summer rainstorms, which explain the presence of fine sediments at the surface of the talus slope. The presence of fine sediments allowed the development of solifluction lobes, which are currently visible on the Les Attelas talus slope surface.

This kind of stratified structure was also observed in several rock glaciers in the Verbier area (Reynard et al., 1999), with the development of lenses of massive ice in cold and humid periods such as the Little Ice Age and important debris accumulation in warmer periods. In this model for the generation of continuous strata in talus slopes, contrary to Sass and Krautblatter (2007), the rockfall inputs are characteristics of the transition periods between two steady states, and not of the cold period. It is possible that, in the periglacial belt, the importance of permafrost degradation in rock walls (more important in transitions towards warm periods) is greater than the intensity of the frost weathering (more important in cold periods), as suggested, for example, by the large number of rockfalls in permafrost areas in the extremely hot and dry summer of 2003 (Gruber et al., 2004; Gruber and Haeberli, 2007; Ravanel et al., 2011).

At the Petit Mont Rouge talus slope, the absence of indices of stratification may indicate that there is no alternation between different processes, and/or that the change in the intensity of rockfall generation is low. From a palaeoclimatic point of view, the protalus rampart located in the lower part of the slope is submitted to the same thermal, glaciological and rheological conditions as a rock glacier (Barsch, 1996). Considering that ice within a rock glacier is probably several centuries old and, therefore, predates recent cold periods such as the Little Ice Age (e.g. Haeberli et al., 1999; Scapozza et al., 2010c), and according to absolute and relative dating of rock glaciers in the European Alps (Dramis et al., 2003; Frauenfelder et al., 2005; Scapozza and Ramelli, 2011), it is possible to conclude that the development of the protalus rampart started in the early phases of the Holocene or, at the latest, after the early-to-mid Holocene temperature optimum (ending around 5000 years BP). This chronological framework is confirmed by relative-age dating of the protalus rampart surface performed by Schmidt hammer rebound values (C. Scapozza, unpublished data). A minimum surface age of about 4000 years BP is therefore proposed. Considering a small talus aggradation since the development of the protalus rampart, the main volume of the Petit Mont Rouge talus slope may have accumulated during a period of considerably higher rates of debris production between the end of the Lateglacial and the middle of the Holocene. This period of enhanced rockfall activity can be connected to the paraglacial slope adjustment phase following the deglaciation (e.g. Church and Ryder, 1972; Ballantyne, 2002).

\section{Conclusion}

Four main conclusions can be drawn from the observations and measurements at the two study sites:

1. The borehole data (observations, stratigraphy and thermal profiles) allowed the permafrost stratigraphy of the talus slopes obtained from the ERT inverted profiles to be validated, for both the distribution of frozen sediments and the depth of the detected structures. Both boreholes and ERT data show an important contrast in ice content between the lower and upper parts of the talus slopes, with the coldest temperatures and the highest resistivities measured in the lower part of the slopes.

2. In both sites, resistivities decrease, borehole temperatures get warmer and the active layer thickness increases upslope, indicating a warming of permafrost and a decrease in ice content. In the upper part of the two talus slopes, borehole temperatures indicate the absence of permafrost at depth. These data prove the model of the permafrost distribution in talus slopes located within the Alpine periglacial belt developed by Haeberli (1975) and Lambiel and Pieracci (2008): in the two study sites, permafrost is present in the lower parts of the talus slope, whereas it is absent in the upper parts.

3. The analysis of the talus structure shows that the permafrost stratigraphy may be an important element of interpretation of the palaeoclimatic significance of an alpine talus slope. In the Les Attelas talus slope, there is a probable relationship between the alternation of layers with different ice content and the climatic fluctuations during the end of the Lateglacial and the Holocene. For the Petit Mont Rouge talus slope, the absence of stratification and the presence of an embryonal active talus rock glacier may indicate that the talus slope developed during a period of enhanced rockfall activity, probably connected to the paraglacial slope adjustment phase after the deglaciation.

4. From a methodological point of view, this work also highlighted the importance of collecting crossing ERT profiles to allow discrimination between real subsurface structures and lateral effects. Moreover, the use of a borehole camera allowed for more precise in situ identification of the stratigraphy than using cuttings only.

\section{Acknowledgements}

This work was funded by the Swiss National Science Foundation (SNF) (project No. 200021-119854). We would like to thank all those who helped in the fieldwork, in particular François Moreau and JeanBaptiste Bosson, and the Sébastien Cheseaux Paravalanches drilling team, in particular Dominic Cheseaux and Guy Udriot. A special thanks to the editor, Dr. Takashi Oguchi, and to the three anonymous reviewers for their useful feedback, as well as Meredith Blake for proofreading the English.

\section{References}

Arenson, L.U., Hoelzle, M., Springman, S.M., 2002. Borehole deformation measurements and internal structure of some rock glaciers in Switzerland. Permafrost and Periglacial Processes 13, 117-135.

Ballantyne, C.K., 2002. Paraglacial geomorphology. Quaternary Science Reviews 21, 1935-2017.

Ballantyne, C.K., Benn, D.I., 1994. Glaciological constrains on protalus rampart development. Permafrost and Periglacial Processes 5, 145-153.

Barsch, D., 1969. Permafrost in der oberen subnivalen Stufe der Alpen. Geographica Helvetica 24, 10-12.

Barsch, D., 1996. Rockglaciers. Indicators for the Present and Former Geoecology in High Mountain Environments. Springer, Berlin/Heidelberg.

Berthling, I., Etzelmüller, B., Isaksen, K., Sollid, J.L., 2000. Rock glaciers on Prins Karls Forland. II: GPR soundings and the development of internal structures. Permafrost and Periglacial Processes 11, 357-369.

Borgatti, L., Soldati, M., 2010. Landslides as a geomorphological proxy for climate change: a record from the Dolomites (northern Italy). Geomorphology 120, 56-64 
Burga, C.A., Perret, R., 1998. Vegetation und Klima der Schweiz seit dem jüngeren Eiszeitalter. Ott Verlag, Thun.

Church, M., Ryder, J.M., 1972. Paraglacial sedimentation: a consideration of fluvial processes conditioned by glaciations. Geological Society of America Bulletin 83, 3059-3071.

Davies, M.C., Hamza, O., Harris, C., 2001. The effect of rise in mean annual temperature on the stability of rock slopes containing ice-filled discontinuities. Permafrost and Periglacial Processes 12, 137-144.

Delaloye, R., 2004. Contribution à l'étude du pergélisol de montagne en zone marginale. Département des Géosciences, Fribourg. Geofocus Vol. 10.

Delaloye, R., Lambiel, C., 2005. Evidence of winter ascending air circulation throughout talus slopes and rock glaciers situated in the lower belt of alpine discontinuous permafrost (Swiss Alps). Norsk Geografisk Tidsskrift 59, 194-203.

Dramis, F., Giraudi, C., Guglielmin, M., 2003. Rock glacier Distribution and Paleoclimate in Italy. Proceedings of the 8th International Conference on Permafrost, Zurich, Switzerland. Balkema, Lisse 1, 199-204.

Francou, B., 1977. Formes d'éboulis élevés en Briançonnais. Revue de Géographie Alpine $65,63-77$.

Francou, B., 1988. Eboulis stratifiés dans les Hautes Andes Centrales du Pérou. Zeitschrift für Geomorphologie 32, 47-76.

Francou, B., Hétu, B., 1989. Eboulis et autres formations de pente hétérométriques: contribution à une terminologie géomorphologique. Notes et Comptes-rendus du groupe de travail "Régionalisation du Périglaciaire" 14, 11-69.

Frauenfelder, R., Laustela, M., Kääb, A., 2005. Relative age dating of alpine rockglacier surface. Zeitschrift für Geomorphologie 49, 145-166.

French, H.M., 1996. The Periglacial Environment2nd edition. Longman, London.

Solifluction and climatic variations in the Holocene. In: Frenzel, B. (Ed.), Paläoklimaforschung and Palaeoclimate Research, 11, pp. 1-387.

Gruber, S., Haeberli, W., 2007. Permafrost in steep bedrock slopes and its temperaturerelated destabilization following climate change. Journal of Geophysical Research 112, F02S18. doi:10.1029/2006JF000547.

Gruber, S., Hoelzle, M., Haeberli, W., 2004. Permafrost thaw and destabilization of Alpine rock walls in the hot summer of 2003. Geophysical Research Letters 31, L13504. doi:10.1029/2004GL020051.

Guglielmin, M., Aldighieri, B., Testa, B., 2003. PERMACLIM: a model for the distribution of mountain permafrost, based on climatic observations. Geomorphology 51, $245-257$.

Haeberli, W., 1975. Untersuchungen zur Verbreitung von Permafrost zwischen Flüelapass and Piz Grialesch (Graubünden). Mitteilungen der VAW/ETH Zürich $17,1-221$.

Haeberli, W., 1985. Creep of mountain permafrost. Internal structure and flow of alpine rock glaciers. Mitteilungen der VAW/ETH Zürich 77, 1-142.

Haeberli, W., Vonder Mühll, D., 1996. On the characteristics and possible origin of ice in rock glacier permafrost. Zeitschrift für Geomorphologie Suppl.-Bd. 104, 43-57.

Haeberli, W., Kääb, A., Wagner, S., Vonder Mühll, D., Geissler, P., Haas, J.N., GlatzelMattheier, H., Wagenbach, D., 1999. Pollen analysis and ${ }^{14} \mathrm{C}$ age of moss remains in a permafrost core recovered from the active rock glacier Murtèl-Corvatsch, Swiss Alps: geomorphological and glaciological implications. Journal of Glaciology 43, $1-8$.

Haeberli, W., Hallet, W., Arenson, L.U., Elconin, R., Humlum, O., Kääb, A., Kaufmann, V. Ladanyi, B., Matsuoka, N., Springman, S.M., Vonder Mühll, D., 2006. Permafrost creep and rock glacier dynamics. Permafrost and Periglacial Processes 17, 189-214.

Harris, C., Vonder Mühll, D., Isaken, K., Haeberli, W., Sollid, J.L., King, L., Holmund, P. Dramis, F., Guglielmin, F., Palacios, D., 2003. Warming permafrost in European mountains. Global and Planetary Change 39, 215-225.

Hauck, C., Vonder Mühll, D., Maurer, H., 2003. Using DC resistivity tomography to detect and characterize mountain permafrost. Geophysical Prospecting 51, 273-284.

Hilbich, C., Marescot, L., Hauck, C., Loke, M.H., Mäusbacher, R., 2009. Applicability of electrical resistivity tomography monitoring to coarse blocky and ice-rich permafrost landforms. Permafrost and Periglacial Processes 20, 269-284

Hoelzle, M., Mittaz, C., Etzelmüller, B., Haeberli, W., 2001. Surface energy fluxes and distribution models of permafrost in European mountain areas: an overview of current developments. Permafrost and Periglacial Processes 12, 53-68.

Jörin, U.E., Stocker, T.F., Schlüchter, C., 2006. Multicentury glacier fluctuations in the Swiss Alps during Holocene. The Holocene 16, 687-704.

Kneisel, C., Hauck, C., Fortier, R., Moorman, B., 2008. Advances in geophysical methods for permafrost investigations. Permafrost and Periglacial Processes 19, 157-178.

Lambiel, C., 2006. Le pergélisol dans les terrains sédimentaires à forte déclivité: distribution, régime thermique et instabilités. : Travaux et recherches, Vol. 33 Institut de Géographie, Lausanne.

Lambiel, C., Pieracci, K., 2008. Permafrost distribution in talus slopes located within the alpine periglacial belt, Swiss Alps. Permafrost and Periglacial Processes 19 293-304

Lambiel, C., Reynard, E., 2001. Regional modelling of present, past and future potential distribution of discontinuous permafrost based on rock glacier inventory in the Bagnes-Hérémence area (Western Swiss Alps). Norsk Geografisk Tidsskrift 55, 219-223.

Lerjen, M., Kääb, A., Hoelzle, M., Haeberli, W., 2003. Local distribution pattern of discontinuous permafrost. A process study at Flüela Pass, Swiss Alps. Proceedings of the 8th International Conference on Permafrost, Zurich, Switzerland., Vol. 2. Balkema, Lisse. pp. 667-672.
Loke, M.H., 2000. Topographic modelling in electrical imaging inversion. 62nd EAGE Conference and Technical Exhibition, Glasgow, Scotland, 29 May-2 June 2000. Extended Abstracts, D-2.

Loke, M.H., Barker, R.D., 1996. Rapid least-squares inversion of apparent resistivity pseudosections using a quasi-Newton method. Geophysical Prospecting 44, 131-152.

Lütschg, M., Stöckli, V., Lehning, M., Haeberli, W., Ammann, W., 2004. Temperatures in two boreholes at Flüela Pass, Eastern Swiss Alps: the effect of snow redistribution on permafrost distribution patterns in high mountain areas. Permafrost and Periglacial Processes 15, 283-297.

Marescot, L., Loke, M.H., Chapellier, D., Delaloye, R., Lambiel, C., Reynard, E., 2003. Assessing reliability of 2D resistivity imaging in mountain permafrost studies using the depth of investigation index method. Near Surface Geophysics 1, 57-67.

Marescot, L., Rigobert, S., Palma Lopes, S., Lagabrielle, R., Chapellier, D., 2006. A general approach for DC apparent resistivity evaluation on arbitrarily shaped 3D structures. Journal of Applied Geophysics 60, 55-67.

Mellor, M., Sellmann, P.V., 1975. General considerations for drill system design. CRREL Technical Report, 64. 1-40.

Otto, J.C., Sass, O., 2006. Comparing geophysical methods for talus slope investigations in the Turtmann valley (Swiss Alps). Geomorphology 76, 257-272.

PERMOS, 2010. In: Noetzli, J., Vonder Mühll, D. (Eds.), Permafrost in Switzerland 2006/ 2007 and 2007/2008. Glaciological Report Permafrost No. 8/9. Cryospheric Commission of the Swiss Academy of Sciences, Zurich.

Phillips, M., 2000. Influences of snow supporting structures on the thermal regime of the ground in alpine permafrost terrain. Eidgenössische Institut für Schnee- und Lawinenforschung, Davos.

Phillips, M., Zenklusen Mutter, E., Kern-Lütschg, M., Lehning, M., 2009. Rapid degradation of ground ice in a ventilated talus slope: Flüela Pass, Swiss Alps. Permafrost and Periglacial Processes 20,1-14.

Pieracci, K., Lambiel, C., Reynard, E., 2008. La répartition du pergélisol dans trois éboulis alpins du massif de la Dent de Morcles (Valais, Alpes suisses). Géomorphologie: relief, processus, environnement 2, 87-97.

Ravanel, L., Allingol, F., Deline, P., Bruno, G., 2011. Les écroulements rocheux dans le Massif du Mont Blanc pendant l'été caniculaire 2003. In: Lambiel, C., Reynard, E., Scapozza, C. (Eds.), La géomorphologie alpine: entre patrimoine et contrainte. Actes du colloque de la Société Suisse de Géomorphologie, 3-5 septembre 2009, Olivone. : Géovisions, Vol. 36. Institut de Géographie, Lausanne, pp. 225-241.

Reynard, E., 1999. Gestion patrimoniale et intégrée des ressources en eau dans les stations touristiques de montagne. Travaux et recherches, Vol. 17. Institut de Géographie, Lausanne.

Reynard, E., Delaloye, R., Lambiel, C., 1999. Prospection géoelectrique du pergélisol alpin dans le massif des Diablerets (VD) et au Mont Gelé (Nendaz, VS). Bulletin de la Murithienne 117, 89-103.

Riseborough, D., Shiklomanov, N., Etzelmüller, B., Gruber, S., Marchenko, S., 2008. Recent advances in permafrost modelling. Permafrost and Periglacial Processes 19, $137-156$

Sass, O., 2006. Determination of the internal structure of alpine talus deposits using different geophysical methods (Lechtaler Alps, Austria). Geomorphology 80, $45-58$.

Sass, O., Krautblatter, M., 2007. Debris flow-dominated and rockfall-dominated talus slopes: genetic models derived from GPR measurements. Geomorphology 86, 176-192.

Scapozza, C., Ramelli, G., 2011. Datazione relativa con il martello di Schmidt delle età di esposizione di alcuni rock glaciers delle Alpi Bleniesi (Ticino, Svizzera). Bollettino della Società ticinese di Scienze naturali 99, 15-24.

Scapozza, C., Lambiel, C., Reynard, E., Fallot, J.-M., Antognini, M., Schoeneich, P., 2010a. Radiocarbon dating of fossil wood remains buried by the Piancabella rock glacier, Blenio Valley (Ticino, Southern Swiss Alps): implications for rock glacier, treeline and climate history. Permafrost and Periglacial Processes 21, 90-96.

Scapozza, C., Lambiel, C., Abbet, D., Delaloye, R., Hilbich, C., 2010b. Internal structure and permafrost characteristics of the Lapires talus slope (Nendaz, Valais). 8th Swiss Geoscience Meeting 2010, Fribourg, Switzerland, 19-20 November 2010. Extended Abstract 7.16, 166-167.

Scapozza, C., Baron, L., Lambiel, C., 2010c. Borehole logging in alpine periglacial talus slopes, Valais Alps, Switzerland. 8th Swiss Geoscience Meeting 2010, Fribourg, Switzerland, 19-20 November 2010. Extended Abstract 10.16, 245-246.

Scapozza, C., Lambiel, C., Gex, P., Reynard, E., 2011. Prospection géophysique multiméthodes du pergélisol alpin dans le sud des Alpes suisses. Géomorphologie: relief, processus, environnement $1 / 2011,15-32$.

Scott, W.J., Sellmann, P., Hunter, J., 1990. Geophysics in the study of permafrost. In: Wars, S. (Ed.), Geotechnical and Environmental Geophysics. Society of Exploration Geophysicists, Tulsa, pp. 355-384.

Shakesby, R.A., 1997. Pronival (protalus) ramparts: a review of forms, processes, diagnostic criteria and palaeoenvironmental implications. Progress in Physical Geography 21, 394-418.

van Steijn, H., Boelhouwers, J., Harris, S., Hétu, B., 2002. Recent research on the nature, origin and climatic relations of blocky and stratified slope deposits. Progress in Physical Geography 26, 551-575.

Vonder Mühll, D. 1992. Evidence of intrapermafrost groundwater flow beneath an active rock glacier in the Swiss Alps. Permafrost and Periglacial Processes 3, 169-173.

Vonder Mühll, D., 1996. Drilling in Alpine permafrost. Norsk Geografisk Tidsskrift 50, 17-24. 